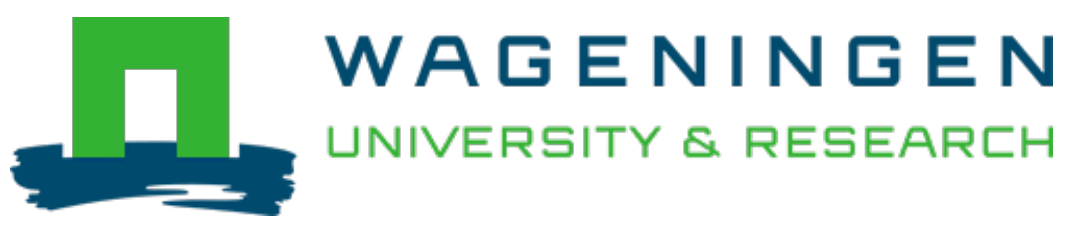

\title{
Mosaic governance for urban green infrastructure: Upscaling active citizenship from a local government perspective
}

\author{
Urban Forestry and Urban Greening \\ Buijs, Arjen; Hansen, Rieke; Jagt, Sander; Ambrose-Oji, Bianca; Elands, Birgit et al \\ https://doi.org/10.1016/j.ufug.2018.06.011
}

This article is made publicly available in the institutional repository of Wageningen University and Research, under the terms of article $25 \mathrm{fa}$ of the Dutch Copyright Act, also known as the Amendment Taverne. This has been done with explicit consent by the author.

Article 25 fa states that the author of a short scientific work funded either wholly or partially by Dutch public funds is entitled to make that work publicly available for no consideration following a reasonable period of time after the work was first published, provided that clear reference is made to the source of the first publication of the work.

This publication is distributed under The Association of Universities in the Netherlands (VSNU) 'Article $25 \mathrm{fa}$ implementation' project. In this project research outputs of researchers employed by Dutch Universities that comply with the legal requirements of Article $25 \mathrm{fa}$ of the Dutch Copyright Act are distributed online and free of cost or other barriers in institutional repositories. Research outputs are distributed six months after their first online publication in the original published version and with proper attribution to the source of the original publication.

You are permitted to download and use the publication for personal purposes. All rights remain with the author(s) and / or copyright owner(s) of this work. Any use of the publication or parts of it other than authorised under article $25 \mathrm{fa}$ of the Dutch Copyright act is prohibited. Wageningen University \& Research and the author(s) of this publication shall not be held responsible or liable for any damages resulting from your (re)use of this publication.

For questions regarding the public availability of this article please contact openscience.library@wur.nl 


\title{
Mosaic governance for urban green infrastructure: Upscaling active citizenship from a local government perspective ${ }^{\text {is }}$
}

\author{
Arjen Buijs ${ }^{\mathrm{a}, *}$, Rieke Hansen ${ }^{\mathrm{b}}$, Sander Van der Jagt ${ }^{\mathrm{c}}$, Bianca Ambrose-Oji ${ }^{\mathrm{d}}$, Birgit Elands ${ }^{\mathrm{a}}$, \\ Emily Lorance Rall ${ }^{\mathrm{b}}$, Thomas Mattijssen ${ }^{\mathrm{a}, \mathrm{e}, \mathrm{f}}$, Stephan Pauleit ${ }^{\mathrm{b}}$, Hens Runhaar ${ }^{\mathrm{a}, \mathrm{c}}$, \\ Anton Stahl Olafsson ${ }^{\mathrm{e}}$, Maja Steen Møller ${ }^{\mathrm{e}}$ \\ ${ }^{a}$ Forest and Nature Conservation Policy Group, Wageningen University, P.O. Box 67, 6700 AC Wageningen, The Netherlands \\ ${ }^{\mathrm{b}}$ Chair for Strategic Landscape Planning and Management, Technical University of Munich, Germany \\ ${ }^{c}$ Copernicus Institute of Sustainable Development, Utrecht University, 3584 CS Utrecht, The Netherlands \\ d Centre for Ecosystems, Society and Biosecurity, Forest Research, Alice Holt, Farnham, England, United Kingdom \\ e Department of Geosciences and Natural Resource Management, University of Copenhagen, Denmark \\ ${ }^{\mathrm{f}}$ Wageningen Economic Research, The Hague, The Netherlands
}

\section{A R T I C L E I N F O}

\section{Keywords:}

Green space

Participation

Stewardship

Self-Governance

Urban ecology

Upscaling

\begin{abstract}
A B S T R A C T
Compact urban development, social demands and austerity measures are increasing pressures on urban greenspace. Meanwhile, active citizens, defined as voluntary individuals or groups who self-organize to contribute to urban green space development, provide ecological and social benefits to urban societies. This has inspired local governments to seek collaborations with non-state actors, including active citizens. However, the diverging aims, place-specific focus, and varying expertise of active citizenship may inhibit its contribution to ecological connectivity and upscaling beyond the local scale.

In this paper, we investigate how "mosaic governance" has potential as a framework for understanding active citizenship, its potential for upscaling and its relationship to strategic UGI planning. Using the policy arrangements approach, we analyse the role of discourse, resources, actors and rules of the game in the upscaling of active citizenship. Based on eight empirical cases from seven European cities, we analyse the diversity of collaborations between local governments and active citizens in greenspace development.

The cases show how active citizens can significantly contribute to UGI planning and implementation, for example by developing large parks with volunteers or designing a network of green corridors. The cases reveal multiple ways citizens and local governments benefit from collaborations, as well as different pathways for upscaling innovative discourses and practices from local communities to formal policy or to other cities. To enable upscaling, UGI planning needs to combine long-term, more formalized and higher-scale strategic approaches with more incremental approaches that correspond with localized, fragmented and informal efforts of local communities. While collaborations between municipalities and active citizenship is not without its difficulties, the examples of upscaling in our cases demonstrate the transformative power active citizens may have towards a more green, just and democratic city.
\end{abstract}

\section{Introduction}

An ever growing body of evidence about urban greenspace shows its fundamental role in assuring urban quality of life by stimulating experiences of nature that positively impact health and well-being (Sushinsky et al., 2017), generating multiple benefits and services such as recreation and climate change adaptation (Haase et al., 2014), and building social cohesion and integration of different social and ethnic groups (Peters et al., 2010). However, more compact urban development and greater social demands continue to increase pressure on greenspace (Haaland and van den Bosch, 2015). This presents national and local governments with particular political, economic and social challenges as they seek to protect, improve and manage greenspace across urban landscapes.

\footnotetext{
This article is part of a special issue entitled "Urban Green Infrastructure - Connecting People and Nature for Sustainable Cities" published at the journal Urban Forestry \& Urban Greening 40C, 2019.

* Corresponding author.

E-mail address: arjen.buijs@wur.nl (A. Buijs).
} 


\subsection{Strategic UGI planning}

Against this backdrop, a call for strategic planning of urban greenspace has emerged, proposing urban green infrastructure (UGI) as a unifying concept for tackling urban challenges such as climate change adaptation, social inequalities or loss of biodiversity (Pauleit et al., 2011). UGI planning is a comprehensive, strategic planning approach to develop networks of urban greenspaces based on four core principles: connectivity of greenspaces, enhancing multifunctionality through combining environmental, social and economic functions of greenspaces, integration of green and grey infrastructure, and social inclusion (Pauleit et al., 2017). UGI planning has both spatial and process dimensions (Hansen et al., 2016). Ecological connectivity is crucial to the spatial dimension, with a strong focus on developing multifunctional networks of spatially connected greenspaces across the city and enhancing the range of UGI benefits. The process dimension relates to governance issues, including efforts to move from top-down decisionmaking towards involving a broad range of non-governmental actors and recognising local needs and expertise based on citizens' everyday experiences (Faehnle et al., 2014; Hansen et al., 2016).

UGI planning approaches have been successfully implemented in many cities across Europe and beyond (Davies et al., 2017). However, several challenges remain, especially regarding the process dimension of UGI planning. Most notably, UGI planning may fall short in its adaptive capacity to align with the dynamics of local governance issues. This is especially true for aligning long-term UGI planning objectives at higher spatial levels with localized, fragmented and informal efforts by local groups of active citizens (Buijs et al., 2016b). Strongly connected with this is citizen trust in governmental actors (Aalbers and Sehested, 2018), and citizens' reluctance to engage with the bureaucratic culture of local governments (van Dam et al., 2015). Despite genuine efforts towards inclusive decision-making, planning processes tend to be "deliberatively incomplete" (Buizer and Van Herzele, 2012), especially in participation of underprivileged groups. Finally, while governmental efforts typically focus on formal and large public greenspaces, informal and small (semi-) private areas are much more difficult to include in strategic planning processes (Andersson et al., 2014).

\subsection{Active citizenship}

These challenges to strategic UGI planning relate to an emerging interest in contributions from active citizenship. Active citizenship is considered a form of social innovation in which citizens act as voluntary producers and co-producers of urban sustainability (Mehmood and Parra, 2013). In contrast to public participation, which is governmentled, active citizenship emerges from self-organisation and the lived experiences of individuals and communities. The motivation of citizens to engage depends upon their values, objectives and strategies connected with what they perceive to be unsatisfied environmental and social needs (Lévesque, 2013). As such, active citizenship may promote action that is neither connected to, nor aligned with, wider government-led plans and policies (Krasny et al., 2014). While active citizenship has been criticised as a mere "disconnected innovator", with no impact beyond the very local scale or as "filling the void left by a retreating welfare state", we are especially interested in understanding how it can contribute to urban greenspace and urban sustainability in a wider sense, including the upscaling of innovating practices to the city scale or beyond (Frantzeskaki et al., 2016).

Active citizenship contributions to UGI creation and maintenance relate to the quantity but also quality of greenspaces (Colding et al., 2013), including, for example, increases in biodiversity and pollinators, climate change adaptation and local food supply (Dennis and James, 2016; van der Jagt et al., 2017). Additional benefits have also been reported, for example activating local communities and enhancing social cohesion and environmental awareness (Mattijssen et al., 2017a; Veen, 2015). However, active citizenship also comes with several of its own challenges, including: a lack of technical capabilities, expertise and skills in dealing with particular forms of UGI and/or the institutional environment, and securing long-term volunteer commitments (Mattijssen et al., 2017b). The often site-focused, place-based attitude of active citizenship initiatives may limit contributions to the ecological connectivity crucial for UGI at a city-scale (Andersson et al., 2014), not only because citizen interests may not tie in with strategic UGI planning goals and processes (Pinto-Correia et al., 2006), but also because of citizens' reluctance towards institutionalisation and to taking up predetermined governmental objectives (van Dam et al., 2015).

These limitations of active citizenship suggest it is important to avoid the "localism trap" (Purcell, 2006): Instead of considering local community actions as intrinsically more democratic and ecologically valuable than higher-scale governmental actions, a more fruitful approach may be to adopt principles from strategic planning to facilitate upscaling and enhancing the ecological output of active citizenship.

\subsection{Linking UGI planning and active citizenship through mosaic governance}

The concept of "mosaic governance" has been proposed to develop mechanisms and interventions that link up active citizenship with a spatially connected network of urban greenspaces that have varying levels of multifunctionality at different scales (Buijs et al., 2016b). Mosaic governance aims to combine the micro-level of active citizenship with the macro-level of strategic urban planning. We define mosaic governance as "the diversity of processes that may facilitate existing active citizenship and stimulate its upscaling through a mix of governance modes and policy interventions tailored to the socio-ecological context of urban landscapes".

The challenge for mosaic governance is to combine the planningbased, long-term vision for spatial greenspace networks with local people's enthusiasm and dedication manifested in locally embedded but usually not spatially interconnected - initiatives from active citizens. Inspired by their own aims, local governments and active citizens may find possibilities for collaboration in order to create more socially, politically and environmentally resilient UGI. In so doing, mosaic governance can be harnessed as an integrative concept for active citizenship to prosper and to increase contributions to UGI protection, maintenance and improvement.

While Buijs et al. (2016b) focused on agenda-setting and highlighted opportunities from mosaic governance, the current paper aims to use the concept of mosaic governance as an analytical lens to investigate real-life collaborations between active citizens and local governments. Accordingly, we distinguish the following research questions:

i) How can we analytically elaborate the concept of mosaic governance?

ii) What examples of mosaic governance can be found in cities across Europe?

iii) Can mosaic governance contribute to the upscaling of active citizenship?

\section{Analytical framework}

To investigate how active citizenship contributes to UGI and how it can be scaled-up through a mosaic governance lens, we combine theory on upscaling with governance theory.

\subsection{Scaling-out and scaling-up of active citizenship}

Upscaling of active citizenship can be achieved in two ways: through scaling-out or through scaling-up (Van Doren et al., 2016b). Scaling-out, the horizontal pathway, refers to either an increase in the impacts or to an increase in number or size of existing practices of active citizenship (Ibid). While analysing the increase in size or number 
is rather straightforward, understanding the impact is much more complex. With our mosaic governance lens, we consider impact from a strategic UGI planning perspective, relating active citizenship efforts to UGI planning aims: enhancing ecological connectivity, multifunctionality, social inclusion and integration of green and grey infrastructure (cf. Hansen et al., 2016).

The vertical pathway, or scaling-up, is about changing the institutional context in which green space management and active citizenship initiatives are situated (Van Doren et al., 2016b). Scaling-up is sometimes referred to as the "transformative potential" of active citizens or other non-state actors (Hajer et al., 2015) or their ability to contribute to "changes on the regime-level" (Geels, 2004). Improving the fit between institutional rules or resources and active citizenship may help emerging or existing examples of active citizenship to thrive and to scale-out (Aalbers and Sehested, 2018). As such, strategic planning needs to include adaptive mechanisms to respond to the emergence of active citizenship (Berkes, 2010). Thus, structural learning by governments from active citizenship practices is crucial to improve the fit between planning and active citizenship. While scaling-out can be facilitated through simple policy instruments such as subsidies or the provision of knowledge (Mees et al., 2014), scaling-up requires more radical changes in local institutions, including rules or urban planning routines (cf. Van Doren et al., 2016b). Another consideration is that scaling-out and scaling-up are entangled, so mechanisms and interventions that facilitate scaling-up of active citizenship will often also impact scaling-out, and vice versa.

\subsection{Understanding mosaic governance processes through the Policy Arrangements Approach}

For a systematic exploration of mosaic governance we use the Policy Arrangements Approach (PAA). A policy arrangement is defined in the PAA as "the way in which a certain policy domain - [such as UGI governance] - is shaped in terms of organisation and substance [...] consisting of four analytical dimensions: 'discourses', 'rules', 'actors' and 'resources"' (Arts et al., 2006). The PAA has been employed to analyse governance arrangements that encompass multiple public and private actors and their interactions and activities (Arts et al., 2006; Lawrence et al., 2013). The PAA is an appropriate framework for this paper because (a) mosaic governance entails a mix of policy arrangements and (b) instruments for supporting and upscaling active citizenship can potentially be found in each of the four dimensions. Below we will briefly discuss the four PAA dimensions and how they may support or upscale active citizenship.

"Discourses" refer to the shared visions and objectives of actors and may range from greening visions to specific (UGI) policy programmes. Successful mosaic governance will combine top-down UGI discourses with the - partly strongly divergent - discourses from active citizens. Additionally, discourses from local governments will implicitly or explicitly include a vision on collaboration with local actors. Conversely, active citizens also develop discourses on the relationship vis-a-vis local governments, typically ranging from a strong preference for autonomy from government interference (Dam et al., 2014) to more collaborative views on partnership and co-creation (Franklin and Marsden, 2015). While scaling-out of discourses relates to copying inspiring active citizenship practices to other communities or places, in a similar way, scaling-up could relate to, as one example, the incorporation of innovative solutions at the governmental level.

"Rules of the game" define the scope of action for local governments as well as for active citizens. This includes informal rules based on customs and traditions, or relations of trust between citizens and local government. It also includes formal rules, which relate to issues such as ownership and rights of use to public lands, ranging from lease, certain permitted uses, urban commons or illegal use and occupation (Colding et al., 2013). Scaling-up often includes changes in especially formal rules, for example in regulations imposed on active citizenship such as obligations around "proper" management of the land, the right to sell produce from the land or to issues of accountability and transparency (van Dam et al., 2015).

"Resources" such as land, money and expertise are crucial for both local governments and active citizens. Local governments almost always have some degree of resources to contribute to UGI, but active citizens may also generate resources through crowdfunding, sponsoring or sales of produce (Mattijssen et al., 2017a). Regardless of funding, UGI initiatives require technical, organisational and cultural knowledge, skills and expertise, which local governments either hold in-house or can obtain from consultants or researchers, but may also originate from the informal or professional knowledge and skills present amongst active citizens themselves. Scaling-out refers to resources being shared across citizens, while scaling-up refers to adjustments in governmental frameworks for structural supply of money, materials or expertise.

The role of "actors" also is important to understand governance arrangements. Especially scaling-out may be relevant here, relating to mobilising new actors, including citizens from disadvantaged communities. Although all types of urban actors engage in place-making and place-keeping activities, including diverse governmental sectors, residents, developers, housing associations, companies and other private land-owners, research institutions and consultants, the focus of this paper is on local governments responsible for UGI and active citizens. Because of the focus on these two actors, our elaborations of actors and coalitions will be rather limited.

Mosaic governance encompasses all four dimensions of the PAA to varying degrees. In stimulating active citizenship, local governments and/or other actors such as NGOs - may employ specific interventions or instruments within the context of mosaic governance to contribute to the scaling-out or scaling-up of active citizenship. Fig. 1 illustrates the concept of mosaic governance.

\section{Methods}

The empirical part is based on comparative case study research (Yin, 2003). The cases were collected in 2015 as part of the GREEN SURGE project, a European collaborative research project on Green Infrastructure and Urban Biodiversity for Sustainable Urban Development and the Green Economy (2013-2017). In the project, we selected in total 32 case studies: 14 case studies from 10 European cities as good practice examples for UGI planning (Hansen et al., 2016) and 18 cases from 16 European cities to illustrate different participatory governance arrangements for the development and management of UGI (Buijs et al., 2016b). Researchers collected data on the role of UGI planning instruments, involved actors, discourses, resources, limitations, success factors and environmental, social and economic effects. To only include those cases most relevant for the scope of this paper, all 32 cases were ranked by the authors on i) significance for mosaic governance (interpreted as substantial collaborations between active citizenship and local governments) and ii) completeness of the information. The eight cases that were ranked "high" on both criteria were included in the dataset (see Fig. 2 for an illustration of the cases).

We used semi-structured interviews with local stakeholders in all cases (2 to 15 interviews per case) as well as reviews of planning documents and other written material. The interviewees all had knowledge of the cases from their city and covered as far as possible the core actor groups relevant for each case, including actors that had a critical view on the cases. To aid analysis of the data, detailed case narratives as well as case tables for cross-case comparison were developed (see Buijs et al., 2016a; Hansen et al., 2016). Using the PAA, we analysed discourses from both the local governments and the active citizenship initiatives. In addition, we analysed the rules and resources relevant for the interplay between local government as well as examples of scaling-out and scaling-up. To ensure analytical consistency and reduce personal biases, the results were deliberated amongst five of the authors and refined in an iterative manner (Patton, 2009). 


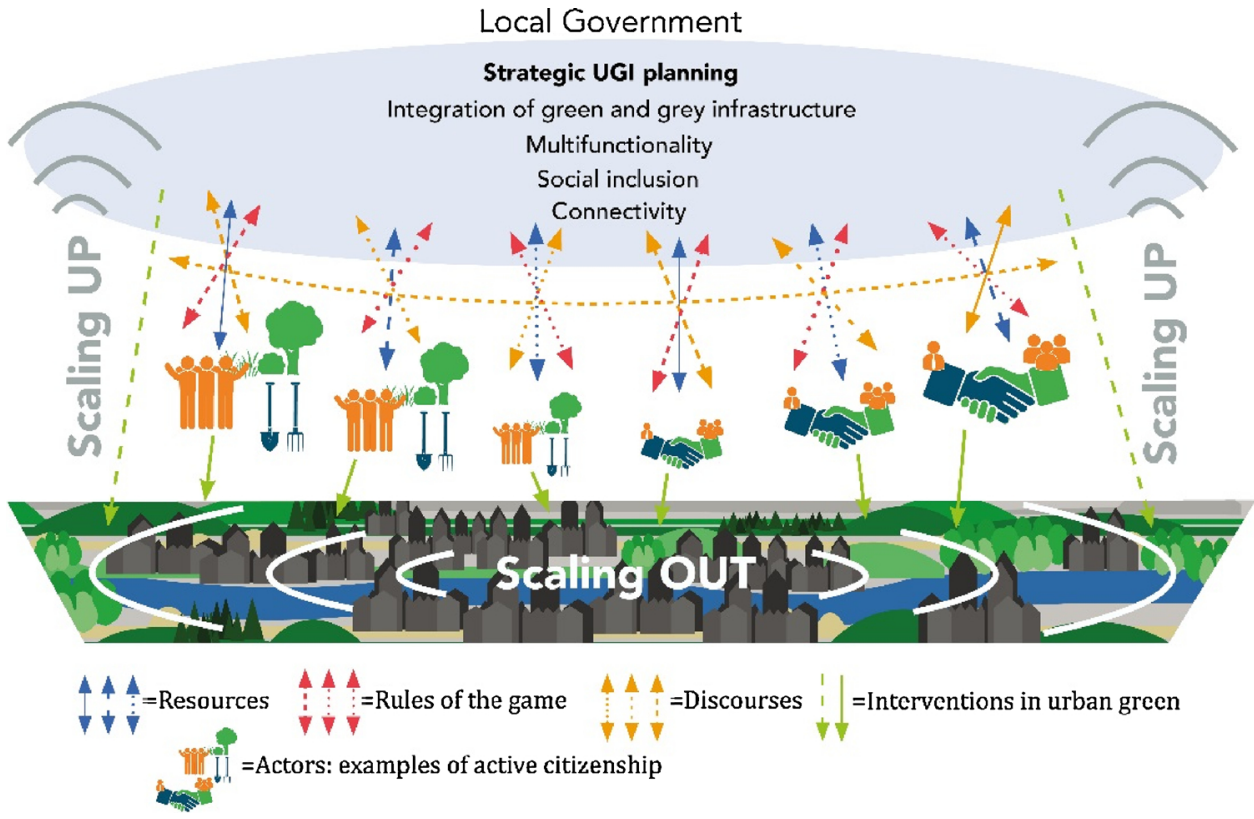

Fig. 1. Graphical representation of the diversity of practices and collaborations in mosaic governance: Bottom: physical manifestations of green, blue and red urban spaces; Middle: icons depicting the diversity of active citizen practices, ranging from local green playgrounds to regional co-creation or comanagement of greenspace (icons based on Buijs et al., 2016b); Top: local government planning. Arrows: analysis of mosaic governance interventions and processes, including resources, rules of the game, discourses, and actors.

\section{Results}

We analysed the cases based on the four dimensions of the PAA discourses, resources, rules of the game and actors - and on the scalingout and scaling-up of active citizenship. Table 1 briefly introduces the cases and summarizes the results. From the eight selected cases, four were initiated by local governments (Aarhus, Berlin2, Lisbon, Utrecht), three by active citizen groups (Amsterdam, Berlin1, Copenhagen), and one through a co-governance approach (Milan). Five of the cases relate to city-wide UGI planning (Berlin1, Berlin2, Copenhagen, Lisbon, Utrecht), while three are concerned with specific environments such as a park (Amsterdam, Aarhus, Milan). In addition to the individual citizens (up to 1000 citizens per case: Milan), local and sometimes national NGOs were involved. Involvement of businesses was very limited in the cases.

\subsection{Discourses}

\subsubsection{Aims regarding urban green infrastructure}

In most cases, the discourses from local governments included strategic UGI planning aims such as increasing connectivity (e.g., linking the targeted area to the greenspace network), while also aiming to meet ecological aims related to climate change adaptation or biodiversity protection (e.g., Aarhus, Amsterdam, Lisbon). Additionally, social aims were strongly represented such as promoting the well-being of citizens through provision of greenspaces for recreation (e.g., Milan, Utrecht), personal fulfilment (Berlin2), improving social cohesion (Aarhus), or food production (Lisbon). While most governmental discourses comprised many UGI aims, including connectivity, the aims of active citizens were usually more focused on individual green plots with emphasis on recreational benefits, social interaction or gardening and food production, but partly also broader environmental aims such as increasing environmental awareness or knowledge about biodiversity (Amsterdam, Copenhagen). Only in Berlin1 and Milan were active citizenship discourses explicitly aimed at contributing to UGI connectivity. Overall, in most cases we saw a remarkable resemblance in discourses between local governments and active citizens. This seemed to be related to the scaling-up of local discourses, such as in Berlin1, or to the development of a shared discourse through co-governance, such as in Milan.
4.1.2. Interest in cooperation between local governments and active citizenship initiatives

The governmental discourses on active citizenship predominantly relate to capitalizing on its potential for additional contributions to UGI, partly in the face of severe municipal budget cuts (Berlin1, Berlin2). In addition, a limited number of local governments also aimed to expand local participatory democracy by embracing the idea that citizens can be developers and managers of UGI, either in the form of small, self-managed plots within a given set of rules (Aarhus, Lisbon), up to large, self-governed parks (Milan). In the Utrecht and Berlin2 cases, discourses on enhancing local governance and community selforganisation also played a prominent role (see Table 1). For example, the Utrecht case provided a framework that enabled citizens to directly influence municipal greenspace decision-making. Furthermore, in some cases, active citizenship was considered as a source of local knowledge on greenspace needs and uses for improving UGI planning (e.g. Aarhus, Berlin1, Copenhagen). In the citizen-led case Amsterdam, the involvement of local government was very limited and despite their efforts, citizens failed to connect on a structural basis to the local government and its resources.

The discourses from active citizens were highly variable due to the number of involved groups and/or individuals. The interest in collaboration by several groups seemed primarily driven by the motivation for additional resources, including funding and the right to use (public) land. In addition, some initiatives aimed for (formal) protection of the self-managed site against urban development (Amsterdam, Milan). Only in a few cases did citizens actively seek collaboration with local governments for the scaling-up of their ideas and practices (Berlin1, Copenhagen). In the Berlin1 case, there was a clear aim to influence local policies and UGI planning decisions by providing a UGI connectivity plan.

\subsection{Interventions and processes for mosaic governance}

Interventions to support active citizenship frequently involved the provision of resources. Active citizens that developed or managed greenspaces often depended upon external financial support, provision of land for free or at low cost and/or provision of materials (e.g., Amsterdam, Lisbon). While the share of municipal subsidies can be high (in Milan around $85 \%$ of the park's annual budget), the active citizen initiatives also leverage a significant amount of non-monetary resources, for example through voluntary work. In Milan, local people 

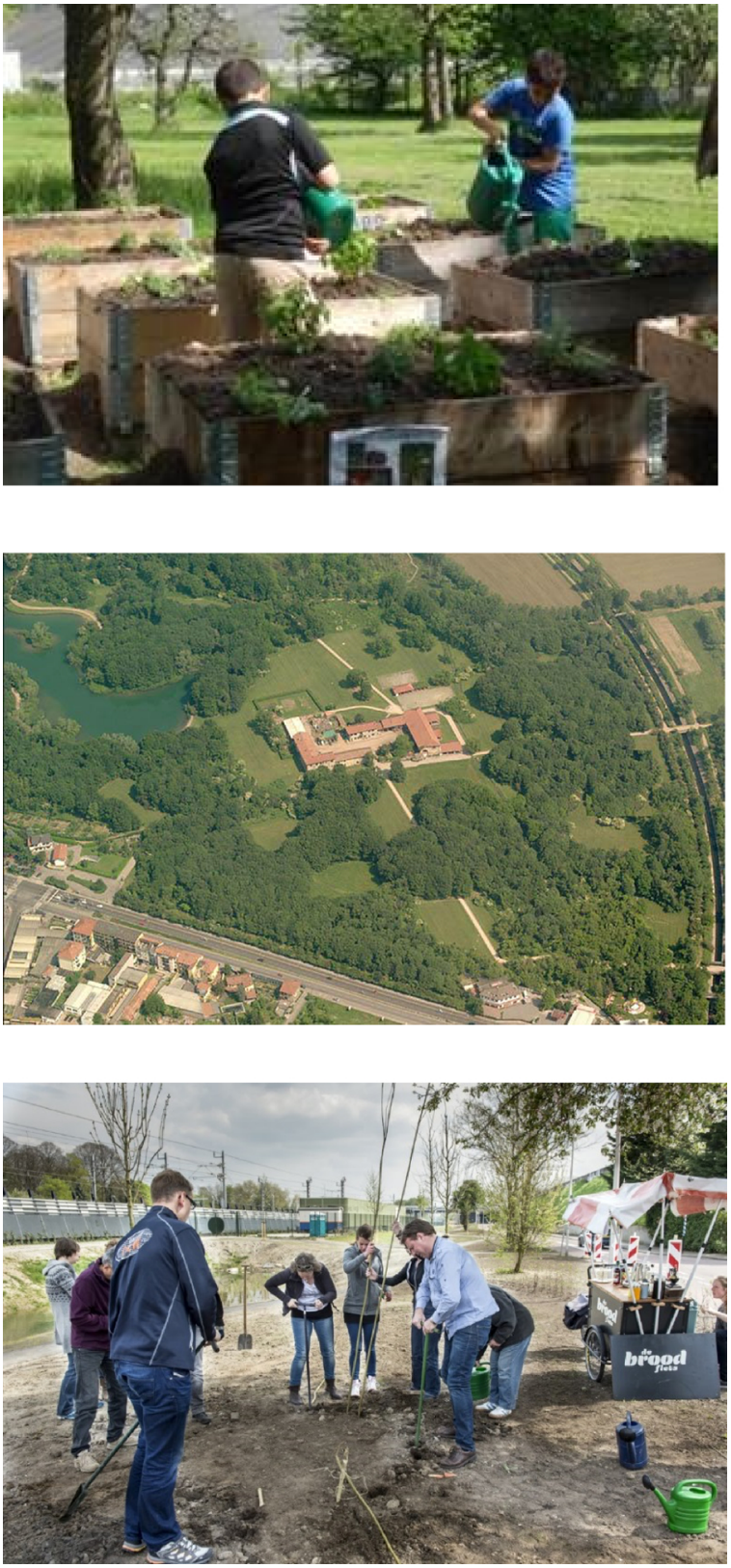

Fig. 2. Examples from our cases. Top: local food production in World Gardens in Aarhus, Middle: Area-view of a section of the 120 ha Boscoincittà Park in Milan. Bottom: One of the project in the Neighbourhood Green Plans project in Utrecht: citizen initiated development of a green playground. Photo 1: from the project website 'Friends of World Gardens' http://www.verdenshaverne.dk/ velkommen (photo: Anett Sällsäter Christiansen); Photo 2: Center for Urban Forestry archive, Milan; Photo 3: Arjen Buijs.

have been heavily involved in park management since the project's beginning, with the number and diversity of actors growing up to thousands of people. Several sections of the park are developed and managed by different groups such as students, scouts and community associations - supervised and facilitated by Italia Nostra.

In those cases where local governments directly engaged with individual citizens, this involved building knowledge through training (Lisbon) or conducting public outreach to inform about options for participation (Aarhus, Utrecht). The provision of inspiring examples and data (Berlin1 and Berlin2) was perceived as an important resource for citizens and local governments alike. In all cases, rules and regulations served to support or embed active citizenship in the local legal and governmental context, e.g., through lease contracts or cooperation agreements that clarify rights and obligations of all involved parties (Amsterdam, Berlin1, Lisbon). In the cases Aarhus and Utrecht, the local governments provided a regulatory framework for cooperative decision-making. For example, in Utrecht the Neighbourhood Green Plans (NGPs) encouraged citizens to submit ideas for local greenspace improvements and provided $€ 5$ million to implement these ideas. The rules of the game were very flexible and ideas were mostly approved if they ensured public accessibility, were supported by at least five local residents and did not contradict municipal policies.

In half of the cases, interventions by local governments were developed on a rather ad-hoc basis, tailored to a specific active citizenship initiative (Amsterdam, Berlin1, Copenhagen, Milan). For example, in Milan, the park was established in 1974 when the municipality of Milan granted a concession to Italia Nostra for redeveloping 35 ha of abandoned farmland. This area was then developed into a park following a co-governance process involving citizens, NGOs and authorities. Only Berlin and Utrecht employed a formalised city-wide strategy on mobilizing active citizenship for urban greenspace management through extensive subsidy schemes (Utrecht) or the development of a comprehensive Urban Landscape Strategy (Berlin2).

\subsection{Scaling-out and scaling-up through mosaic governance}

We observed several examples of scaling-out that were outcomes of explicit efforts from either local government (Lisbon, Utrecht) or from active citizens (Berlin1, Copenhagen). The kinds of scaling-out observed especially involved increases in the number or size of local initiatives, less so in an increase in impact through, for example, increased connectivity (Berlin1 and Lisbon being notable exceptions). In the case of Berlin2, the Urban Landscape Strategy acted as a starting point for a broader municipal discourse on active citizenship in UGI development. Similarly, the Utrecht case was aimed at engaging (more) citizens in UGI development. Additionally, we observed spatial scalingout within some of the active citizenship initiatives, such as the stepwise expansion of the park in Milan through land acquisitions or the development of new greenspaces in Utrecht. The Milan case managed to scale-out over time to an area of 120 ha including woodlands, meadows, wetlands and allotment gardens. In Utrecht, the NGP strategy resulted in 140 implemented projects across the ten neighbourhoods of the city. In Lisbon and Berlin1, strategic planning aims related to increasing connectivity were explicitly included in scaling-out processes.

In several cases we also observed processes of scaling-up. This was likely most profound in Berlin1 and Copenhagen, where innovative practices initially developed by active citizens have since been incorporated within formal policies and programmes. In Berlin1, the initiators managed to scale-up the idea of the path network to the local government, who approved the suggested network of 20 paths and included it in their formal UGI planning discourse. The implementation of the network is prioritized in the current Landscape Programme and significant resources to implement the network were allocated. In Copenhagen, the upscaling of the urban foraging app resulted in the City of Copenhagen developing a 'Food Forest' to be designed in collaboration with Byhøst and citizens. In Aarhus, the citizen initiative managed to promote their idea of a world garden for inclusion in the restoration plan. In the Utrecht case, active citizens in one of the neighbourhoods expressed concern about the lack of scoring criteria for the ecological connectivity of proposed greenspace plans. Through their efforts, they managed to steer allocation of NGP funding towards more focus on ecological connectivity.

Additionally, other initiatives achieved formal recognition such as legal protection, which is important to their long-term stability (Milan). The cases also included examples demonstrating how working together facilitated the institutionalisation and standardisation of strategic cooperation between local governments and active citizen groups (e.g. Milan, Utrecht). For example, in Berlin1 the corridor network is now developed, maintained and promoted in cooperation with 


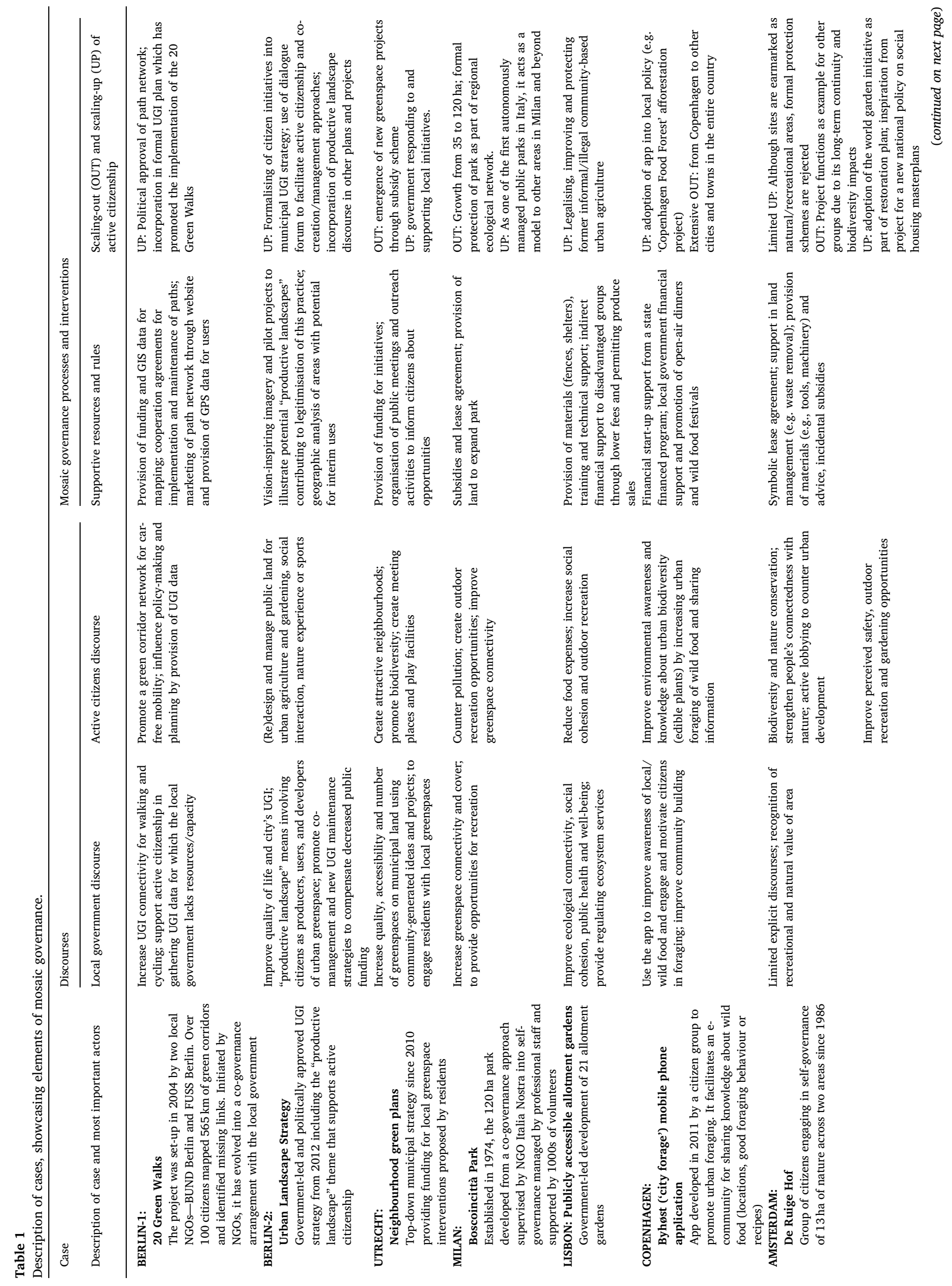


governmental and non-governmental actors.

The cases Berlin2 and Copenhagen demonstrate how deliberate creation of a discourse (on the "productive landscape" strategy or on "urban foraging") can help to bring different actors together and thus potentially spark new forms of collaboration or development of new policies. Likewise, successful pilots such as the Milan case supported other initiatives and created acceptance for such arrangements. Being the first of its kind and perceived as very successful, Boscoincittà has inspired the development of similar parks around Milan and elsewhere in Europe. With this, it has likely contributed to the scaling-up of similar co-governance models for UGI development. Other cases also acted as inspiration; the Copenhagen case raised awareness for urban foraging in other cities across Denmark while experiences from the Aarhus case were taken into account for a new national policy on social housing masterplans.

\section{Discussion and conclusions}

\subsection{The framework of mosaic governance}

We have demonstrated how our novel conception of mosaic governance has potential as a framework for understanding and operationalising urban environmental governance that has both spatial and process elements. The framework highlights how local government can work together with active citizens operating at different spatial scales to better develop multifunctional UGI, while recognising the relative autonomy of active citizens.

Empirically, this paper provides insight into how mosaic governance is emerging in European cities through a range of interactions between actors, discourses, resources and rules of the game. The eight cases described illustrate the variety in modes of governance, ranging from smaller-scale self-governance projects with only limited involvement of local government, to examples of larger and more intensive cogovernance efforts. We observed examples of collaborations which emerge rather autonomously from joint interests. However, we also see several examples with deliberate interventions from actors - whether local governments or active citizens - to actively build relations. Although active citizenship tends to have rather frail connections with government actors and institutions (de Wilde et al., 2014), many of our cases show that involvement of government actors is critical to scalingup and can play a key role in scaling-out.

Our cases demonstrate that mosaic governance has the potential to help local authorities realise their strategic UGI development goals, for example, by complementing and enriching top-down planning with local initiatives, building legitimacy for local greenspace enhancements and reducing the participation gap. Moreover, our research indicates it is core to mosaic governance to capitalise on the long-term visions developed in strategic UGI planning. Discourses and activities emerging from active citizenship tend to be more local and fragmented. The collaborative and place-based logic of active citizenship, compared to the rational logic of strategic planning, requires a more dynamic, incremental and adaptive planning approach from local governments (Favoreu et al., 2016). Such an incremental approach also contributes to the adaptive capacity of governmental planning and other formal processes to align with the micro-dynamics of local communities. This also includes the development of facilitating and networking capacity of public managers to relate to local informal networks (Franklin and Marsden, 2015) and the ability of governments to switch between leading and following (Westerink et al., 2017). This requires subtle manoeuvring between long-term strategic planning and more incremental approaches.

Our formulation of mosaic governance combines insights from related approaches, such as landscape governance approaches (Arts et al., 2017), polycentric governance (Ostrom, 2010) and multi-level governance (Hooghe and Marks, 2001). Mosaic governance shares the spatial component with landscape governance, which also explicitly 
Table 2

Examples of interventions that may contribute to scaling-out or scaling-up from our cases (in italics) and other studies (not in italics). Superscripts refer to other studies: $1=$ (Favoreu et al., 2016), $2=$ (Salverda et al., 2016), 3=(Van der Jagt et al., 2017), $4=$ (Colding et al., 2013), $5=$ (Van Doren et al., 2016b); $6=$ (Van Doren et al., 2016a). No superscripts: this study.

\begin{tabular}{|c|c|}
\hline Dimensions & Interventions for scaling-out and / or scaling-up \\
\hline Actors & $\begin{array}{l}\text { - Actively seek new groups of citizens } \\
\text { - Use of facilitators, such as NGOs } \\
\text { - Develop informal or formal collaborations and partnerships } \\
\text { - Matchmaking events }{ }^{2} \\
\text { - Increase networking capacity of public servants }{ }^{1,2} \\
\text { - Appoint public servants to link to and facilitate active } \\
\text { citizenship }^{6}\end{array}$ \\
\hline Resources & $\begin{array}{l}\text { - Provide access to land (informal, right of use, lease) } \text { - }^{3,4} \\
\text { - Provide subsidies (generic or specific) } \\
\text { - Rent out equipment } \\
\text { - Training and capacity building }{ }^{3} \\
\text { - Codify knowledge obtained in active citizenship and share } \\
\text { publicly } \\
\text { - Allocate additional resources to social groups with limited } \\
\text { - Fultural capital } \\
\text { - Facilitate the building of social and cultural capital }{ }^{1,3} \\
\text { - } \text { groups }^{3,5} \\
\text { - Provide loans under favourable conditions }\end{array}$ \\
\hline Rules of the game & $\begin{array}{l}\text { - Develop framework of pre-set rules (for providing } \\
\text { resources, for structuring UGI development processes) } \\
\text { - Develop regulatory framework for use of public land by } \\
\text { active citizens }{ }^{4} \\
\text { - Establish a front-office for active citizenship }{ }^{6} \\
\text { - Enable pilots with flexible rules and regulations }{ }^{2} \\
\text { - Use of informal narratives for accountability, such as } \\
\text { storytelling }{ }^{2}\end{array}$ \\
\hline $\begin{array}{l}\text { (Change in) } \\
\text { Discourses }\end{array}$ & $\begin{array}{l}\text { - Pilots to showcase practices or stimulate mutual learning } \\
\text { - Responsive and facilitative attitude towards initiatives of } \\
\text { active citizens } \\
\text { - Recognition of citizens as important actors in policies or } \\
\text { - UGI plans } \\
\text { - Awareness raising in communities } \\
\text { - Increasing the status of active citizenship through e.g., } \\
\text { formal recognition or ambassadorship of an alderman }{ }^{2}\end{array}$ \\
\hline
\end{tabular}

takes into account the natural features of -usually non-urban- landscapes, including the value of spatial networks. However, mosaic governance has an explicit focus on grassroots and bottom-up processes and more explicitly takes into account the socio-cultural diversity of residents and communities which are an integral and unique feature of the urban context. Although multi-level governance and polycentric governance approaches often focus on formal or more institutionalised actors, they explicitly recognise the socio-cultural diversity of actors and the relevance of self-organisation for nature resource management (Ostrom, 2010). Its focus on the diversity of actors, formal and informal rules and mechanisms, and the multiplicity of scales (Bissonnette et al., 2018) are all relevant for active citizenship in urban greenspace. However, the relevance of spatial connectivity - ecological, recreational and socio-cultural - is less elaborated upon.

Mosaic governance explicitly embeds the social network of formal and (especially) informal actors and institutions into urban greenspaces and the spatial dimension of strategic urban planning (cf. Ernstson et al., 2010). It is exactly this combination of spatial diversity, sociocultural diversity and institutional diversity, enacted on different spatial scales within the context of strategic planning processes and governmental interactions, which constitutes mosaic governance.

\subsection{Potentials of mosaic governance for supporting and upscaling active citizenship}

Not all active citizen groups were equally motivated to seek extensive collaborations with municipalities beyond securing resources.
This result confirms previous findings that suggest that resources - land, money, knowledge - are a critical aspect of mosaic governance which may offer openings for further collaborations and upscaling (Van Doren et al., 2016b). Our cases also suggest that once collaborations emerge, negotiating the informal as well as the formal rules of the game also become an important element of mosaic governance. This for example relates to issues of formal and informal access and use of public land (cf. Colding et al., 2013), or to informal citizen modes of connecting with disadvantaged populations that may become adopted and formalised by governments. Discourses are a surprisingly important element facilitating the scaling-out of innovative citizenship practices, and a certain congruence of governmental and active citizenship discourse is needed for successful collaboration and diffusion of practices. We observed governmental administrators adopting and integrating ideas and concepts from active citizenship initiatives around increasing ecological connectivity and the potential of urban gardening or urban foraging to meet social justice goals into policies and UGI planning processes. The "20 Green Walks" case in Berlin showed very clearly how a responsive government can support and scale-up a local initiative into UGI planning. We also saw how active citizenship initiatives acted as pilot projects to test new UGI approaches, or developed into good practice examples that inspired other initiatives in the same city or in other places (cf. Frantzeskaki et al., 2016; Van Doren et al., 2016b). We further observed that the role of citizens and active citizenship initiatives as strong actors in the creation and management of greenspaces as well as the development of policies and UGI planning runs contrary to views such as those of Westerink et al. (2017) and Attuyer (2015), who argue that their agency is limited.

Upscaling mosaic governance depends not only on actors known to government, or those who already form part of the "civic core", but also on mobilizing new actor groups or individuals. We agree with De Wilde et al (2014; p3379), that "community participation cannot be considered in isolation from issues such as an uneven distribution of power and resources". As such, the current change in paradigm where governments outsource the delivery of public services such as urban greenspace to businesses and communities has significant impacts on democratic values, including equality, transparency and environmental justice (Kabisch and Haase, 2014; Wagenaar et al., 2015). This emphasises the role of NGOs or other organisations who can act as information brokers in mobilising the full diversity of citizens, helping them to gain UGI-related knowledge and developing the discourse and aims of active citizenship in a way that corresponds with the formal and informal rules structuring governmental UGI planning action. Such an important role for NGOs as powerful actors in urban environmental management has been noted in other work too (Ernstson et al., 2010; van der Jagt et al., 2017), but their role in scaling-up and scaling-out needs to be emphasised. They offer organisational capacity, technical capabilities and expert knowledge of UGI planning issues and the institutional environment that may be supportive or even necessary for successfully creating UGI plans or managing larger greenspaces through active citizenship.

As illustrated in our cases, specific interventions from local governments or NGOs may facilitate the upscaling of active citizenship. Table 2 gives an overview of the interventions illustrated in our cases, expanded with evidence from other research.

\subsection{Challenges of mosaic governance and future developments}

Several scholars and practitioners signal the potential negative impacts of government agents reaching out to active citizens, especially their incorporation into neo-liberal agendas which threaten citizen empowerment and its innovative potential (Aiken, 2017; e.g. Attuyer, 2015; Wagenaar et al., 2015). Indeed, we witnessed that reduced funding increases the imperative for self-mobilisation of active citizens (cf. Buijs et al., 2014), which may signal the danger that active citizenship becomes instrumental "gap filling" to replace previous 
governmental efforts (Frantzeskaki et al., 2016), including the danger that "rights to local voice remain limited and the emerging forms provide little scope to influence (declining) local services and (still centralised) planning decisions" (Pill and Bailey, 2014 pp. 161). The danger of co-option signalled in literature (Wagenaar et al., 2015) is not very apparent in our cases, although more in-depth case studies may be needed to reveal such subtle mechanisms. Our cases suggest that there is a fluid relationship, where the balance between how far citizens and their active citizenship influence government and how far they remain independent and self-serving fluctuates spatially and temporally. Certainly, while mosaic governance may present a danger of entrapment in existing power structures (Swyngedouw, 2005), its potential contribution to upscaling also opens up the possibility of avoiding the "localist trap" (Born and Purcell, 2006). Active citizenship that is not up-scaled or out-scaled through local institutions, formal or informal, simply remains a set of local practices that produces small and incremental changes limited to the neighbourhood scale (Aalbers and Sehested, 2018; de Wilde et al., 2014). Just as ecological connectivity is crucial to maximise the biological potential of greenspaces, social and political connectivity is crucial for active citizenship to imbue its full transformative potential (Wagenaar et al., 2015).

Remaining challenges for research into mosaic governance relate to further unravelling enabling factors for mosaic governance, as well as to improving our understanding of the mechanisms that contribute to the scaling-out and scaling-up of active citizenship. Our current set of cases only act as illustrations of such factors and processes, and lack the indepth analysis to fully capture the range of dynamics involved. The PAA concept which has been used to understand governance in a number of other natural resource contexts such as urban forestry (Lawrence et al., 2013) and water management (Wiering and Immink, 2006) has provided a useful lens to assess the state of the art of this novel concept and to identify some of the supporting and limiting key factors. In our analysis, it also prompted us to consider the influence of discourse on the emergence of mosaic governance. Further investigations may also benefit from adopting other frameworks of analysis, for example employing a multi-level perspective to build on transition theory (Kemp et al., 2007) or social innovation theory (Moulaert et al., 2013). In addition, taking a longitudinal approach may help to identify critical processes and interventions for upscaling active citizenship (Mattijssen et al., 2017b), including investigating the endurance and institutional effects of previous waves of active citizenship for the environment, such as in the 60 's and early 70 's or the late 80 's. A final way forward relates to contrasting the motivations and aims that inspire individual citizens with aims from local governments and the individuals working there (Spijker and Parra, 2017).

\section{Conclusions}

In this paper, we have illustrated processes of mosaic governance based on eight European case studies. The cases show how harnessing the desire, enthusiasm and capacity of citizens to shape their living environment can help local governments to meet demands for UGI benefits. They also provide insight into the multifaceted nature of mosaic governance, conceptualised as the multitude of governance processes in which local governments collaborate with multiple grassroots initiatives or a large amount of individual citizens. Collaborations may vary between ad-hoc financial support and long-term collaborations with intensive forms of co-governance. The institutional culture of local governments and the specific socio-cultural and environmental context plays a strong role in the potential success of active citizenship for enhancing UGI. A point of emphasis is that mosaic governance can take many forms, but, in general, stands for a widening of governance arrangements between local governments and the broad variety of potential urban actors. Nevertheless, often limited municipal resources mean there is a need to make informed decisions on how to enable and upscale active citizenship to increase its contribution to UGI. While enabling active citizenship is not without its difficulties, the examples of upscaling in this study also demonstrate the transformative power active citizens may have towards a more green, just and democratic city.

\section{Funding}

This work was supported by the European Union's Research and Innovation funding programme for 2007-2013 FP 7 (FP7ENV.2013.6.2-5-603567).

\section{Acknowledgements}

This research has been part of GREEN SURGE, a collaborative research project, and would not have been possible without the collaboration of our respondents and the support from many colleagues. We gratefully thank all project partners that contributed to the case studies, in particular Ole Hjorth Caspersen, Yole DeBellis, Sabrina Erlwein, Ruud Otten, Werner Rolf and Artur Santos.

\section{References}

Aalbers, C.B.E.M., Sehested, K., 2018. Critical upscaling. How citizens' initiatives can contribute to a transition in governance and quality of urban greenspace. Urban For. Urban Green. 29, 261-275.

Aiken, G.T., 2017. The politics of community: togetherness, transition and post-politics. Environ. Plann. A 49, 2383-2401.

Andersson, E., Barthel, S., Borgström, S., Colding, J., Elmqvist, T., Folke, C., Gren, A. 2014. Reconnecting cities to the biosphere: stewardship of green infrastructure and urban ecosystem services. Ambio 43, 445-453.

Arts, B., Leroy, P., Van Tatenhove, J., 2006. Political modernisation and policy arrangements: a framework for understanding environmental policy change. Public Organ. Rev. 6, 93-106.

Arts, B., Buizer, M., Horlings, L., Ingram, V., Van Oosten, C., Opdam, P., 2017. Landscape approaches: a State-of-the-art review. Ann. Rev. Environ. Resour. 439-463.

Attuyer, K., 2015. When conflict strikes: contesting neoliberal urbanism outside participatory structures in inner-city Dublin. Int. J. Urban Regional Res. 39, 807-823.

Berkes, F., 2010. Devolution of environment and resources governance: trends and future. Environ. Conserv. 37, 489-500.

Bissonnette, J.F., Blouin, D., Dupras, J., Chion, C., Bouthillier, L., 2018. Comparing polycentric configuration for adaptive governance within community forests: case studies in Eastern North America. Int. J. Commons 12, 352-377.

Born, B., Purcell, M., 2006. Avoiding the local trap: scale and food systems in planning research. J. Plan. Educ. Res. 26, 195-207.

Buijs, A., Mattijssen, T., Arts, B., 2014. "The man, the administration and the counterdiscourse": an analysis of the sudden turn in Dutch nature conservation policy. Land Use Policy 38, 676-684.

Buijs, A., Elands, B., Havik, G., Ambrose-Oji, B., Gerőházi, E., Jagt, A.V.D., Mattijssen, T., Møller, M.S., Vierikko, K., 2016a. Innovative Governance of Urban Green Spaces. Learning from 18 Innovative Examples Across Europe. Wageningen University, Wageningen.

Buijs, A.E., Mattijssen, T.J., Van der Jagt, A.P., Ambrose-Oji, B., Andersson, E., Elands, B.H., Steen Møller, M., 2016b. Active citizenship for urban green infrastructure: fostering the diversity and dynamics of citizen contributions through mosaic governance. Curr. Opin. Environ. Sustain. 22, 1-6.

Buizer, M., Van Herzele, A., 2012. Combining deliberative governance theory and discourse analysis to understand the deliberative incompleteness of centrally formulated plans. For. Policy Econ. 16, 93-101.

Colding, J., Barthel, S., Bendt, P., Snep, R., van der Knaap, W., Ernstson, H., 2013. Urban green commons: insights on urban common property systems. Glob. Environ. Change 23, 1039-1051.

Dam, v.R.I., Duineveld, M., During, R., 2015. Delineating active citizenship: the subjectification of citizens' initiatives. J. Environ. Policy Plan. 7 (2), 163-179.

Davies, C., Rall, E.L., Hansen, R., Stephan, P., Lafortezza, R., 2017. Urban green infrastructure in Europe: Is greenspace planning and policy compliant? Land. Use Policy 69 (Supplement C), 93-101.

de Wilde, M., Hurenkamp, M., Tonkens, E., 2014. Flexible relations, frail contacts and failing demands: how community groups and local institutions interact in local governance in the Netherlands. Urban Stud. 51, 3365-3382.

Dennis, M., James, P., 2016. User participation in urban green commons: exploring the links between access, voluntarism, biodiversity and well being. Urban For. Urban Green. 15, 22-31.

Ernstson, H., Barthel, S., Andersson, E., Borgström, S.T., 2010. Scale-crossing brokers and network governance of urban ecosystem services: the case of stockholm. Ecol. Soc. 15.

Faehnle, M., Bäcklund, P., Tyrväinen, L., Niemelä, J., Yli-Pelkonen, V., 2014. How can residents' experiences inform planning of urban green infrastructure?: Case Finland. Landsc. Urban Plan. 130, 171-183.

Favoreu, C., Carassus, D., Maurel, C., 2016. Strategic management in the public sector: a 
rational, political or collaborative approach? Int. Rev. Adm. Sci. 82, 435-453.

Franklin, A., Marsden, T., 2015. (Dis)connected communities and sustainable placemaking. Local. Environ. 20, 940-956.

Frantzeskaki, N., Dumitru, A., Anguelovski, I., Avelino, F., Bach, M., Best, B., Binder, C., Barnes, J., Carrus, G., Egermann, M., Haxeltine, A., Moore, M.L., Mira, R.G., Loorbach, D., Uzzell, D., Omman, I., Olsson, P., Silvestri, G., Stedman, R., Wittmayer, J., Durrant, R., Rauschmayer, F., 2016. Elucidating the changing roles of civil society in urban sustainability transitions. Curr. Opin. Environ. Sustain. 22, 41-50.

Geels, F.W., 2004. From sectoral systems of innovation to socio-technical systems: insights about dynamics and change from sociology and institutional theory. Res. Policy 33, 897-920.

Haaland, C., van den Bosch, C.K., 2015. Challenges and strategies for urban green-space planning in cities undergoing densification: a review. Urban For. Urban Green. 14, 760-771.

Haase, D., Larondelle, N., Andersson, E., Artmann, M., Borgström, S., Breuste, J., GomezBaggethun, E., Gren, Å., Hamstead, Z., Hansen, R., Kabisch, N., Kremer, P., Langemeyer, J., Rall, E.L., McPhearson, T., Pauleit, S., Qureshi, S., Schwarz, N., Voigt, A., Wurster, D., Elmqvist, T., 2014. A quantitative review of urban ecosystem service assessments: concepts, models, and implementation. AMBIO 43, 413-433.

Hajer, M., Nilsson, M., Raworth, K., Bakker, P., Berkhout, F., de Boer, Y., Rockström, J., Ludwig, K., Kok, M., 2015. Beyond cockpit-ism: Four insights to enhance the transformative potential of the sustainable development goals. Sustain. (Switz.) 7, $1651-1660$

Hansen, R., Rolf, W., Santos, A., Luz, A.C., Száraz, L., Tosics, I., Vierikko, K., Rall, E. Davies, C., Pauleit, S., 2016. Advanced Urban Green Infrastructure Planning and Implementation: Innovative Approaches and Strategies from European Cities, GREEN SURGE Deliverable 5.2. Available from:. http://greensurge.eu/working-packages/ wp5/.

Hooghe, L., Marks, G., 2001. Types of multi-level governance. Eur. Online Integr. Pap. 5, $1-24$.

Kabisch, N., Haase, D., 2014. Green justice or just green? Provision of urban green spaces in Berlin, Germany. Landsc. Urban Plan. 122, 129-139.

Kemp, R., Loorbach, D., Rotmans, J., 2007. Transition management as a model for managing processes of co-evolution towards sustainable development. Int. J. Sustain. Dev. World Ecol. 14, 78-91.

Krasny, M.E., Crestol, S.R., Tidball, K.G., Stedman, R.C., 2014. New York City's oyster gardeners: memories and meanings as motivations for volunteer environmental stewardship. Landsc. Urban Plan. 132, 16-25.

Lawrence, A., De Vreese, R., Johnston, M., Konijnendijk van den Bosch, C.C., Sanesi, G., 2013. Urban forest governance: towards a framework for comparing approaches. Urban For. Urban Green. 12, 464-473.

Lévesque, 2013. Social innovation in governance and public management systems: towards a new paradigm? In: Moulaert, F., MacCallum, D., Mehmood, A., Hamdouch, A. (Eds.), The International Handbook on Social Innovation. Collective Action, Social Learning and Transdisciplinary Research. Edward Elgar, Northhampton, pp. 25-39.

Mattijssen, T., Buijs, A., Elands, B., Arts, B., 2017a. The 'green' and 'self' in green selfgovernance - a study of 264 green space initiatives by citizens. J. Environ. Policy Plan. 1-18.

Mattijssen, T.J.M., van der Jagt, A.P.N., Buijs, A.E., Elands, B.H.M., Erlwein, S., Lafortezza, R., 2017b. The long-term prospects of citizens managing urban green space: from place making to place-keeping? Urban For. Urban Green. 26, 78-84.

Mees, H.L.P., Dijk, J., van Soest, D., Driessen, P.P.J., van Rijswick, M.H.F.M.W., Runhaar, H., 2014. A method for the deliberate and deliberative selection of policy instrument mixes for climate change adaptation. Ecol. Soc. 19.

Mehmood, A., Parra, C., 2013. Social innovation in an unsustainable world. In: Moulaert, F., MacCallum, D., Mehmood, A., Hamdouch, A. (Eds.), The International Handbook on Social Innovation. Collective Action, Social Learning and Transdisciplinary
Research. Edward Elgar, Northhampton, pp. 53-66.

Moulaert, F., MacCallum, D., Mehmood, A., Hamdouch, A., 2013. The International Handbook on Social Innovation. Collective Action, Social Learning and Transdisciplinary Research. Edward Elgar, Northhampton.

Ostrom, E., 2010. Beyond markets and states: polycentric governance of complex economic systems. Am. Econ. Rev. 100, 641-672.

Patton, M.Q., 2009. Qualitative Research and Evaluation Methods. Sage, Thousand Oaks, Calif., London.

Pauleit, S., Liu, L., Ahern, J., Kazmierczak, A., 2011. Multifunctional green infrastructure planning to promote ecological services in the city. In: Niemelä, J. (Ed.), Urban Ecology. Oxford Univ. Press, Oxford, pp. 272-285.

Pauleit, S., Hansen, R., Rall, E.L., Zölch, T., Andersson, E., Luz, A.C., Szaraz, L., Tosics, I., Vierikko, K., 2017. Urban landscapes and Green infrastructure. In: Shugart, H. (Ed.), Oxford Research Encyclopedia of Environmental Science (Vol. Environment and Human Health, Management and Planning). Oxford University Press, USA.

Peters, K., Elands, B., Buijs, A., 2010. Social interactions in urban parks: stimulating social cohesion? Urban For. Urban Green. 9, 93-100.

Pill, M., Bailey, N., 2014. The potential for neighbourhood regeneration in a period of austerity: changing forms of neighbourhood governance in two cities. J. Urban Regen. Renew, 7, 150-163.

Pinto-Correia, T., Gustavsson, R., Pirnat, J., 2006. Bridging the gap between centrally defined policies and local decisions - towards more sensitive and creative rural landscape management. Landsc. Ecol. 21, 333-346.

Purcell, M., 2006. Urban democracy and the local trap. Urban Stud. 43, 1921-1941.

Omgaan met Salverda, I., Dana Kamphorst, Marcel Pleijte, Arjen Buijs, Josine Donders. 2016: Groene burgerinitiatieven. Hoe doe je dat als provincie? (Green citizens initiatives. How to deal with them as regional authority?). WENR, Wageningen.

Spijker, S.N., Parra, C., 2017. Knitting green spaces with the threads of social innovation in Groningen and London. J. Environ. Plan. Manag. 1-22.

Sushinsky, J.R., Rhodes, J.R., Shanahan, D.F., Possingham, H.P., Fuller, R.A., 2017 Maintaining experiences of nature as a city grows. Ecol. Soc. 22.

Swyngedouw, E., 2005. Governance innovation and the citizen: the janus face of governance-beyond-the-state. Urban Stud. 42, 1991-2006.

van Dam, R., Salverda, I., During, R., 2015. Strategies of citizens' initiatives in the Netherlands: connecting people and institutions. Crit. Policy Stud in press.

van der Jagt, A.P.N., Szaraz, L.R., Delshammar, T., Cvejić, R., Santos, A., Goodness, J., Buijs, A., 2017. Cultivating nature-based solutions: the governance of communal urban gardens in the European Union. Environ. Res. 159, 264-275.

Van Doren, D., Driessen, P.P.J., Runhaar, H., Giezen, M., 2016a. Urban studies. Scaling-up Low-Carbon Urban Initiatives: Towards a Better Understanding.

Van Doren, D., Giezen, M., Driessen, P.P.J., Runhaar, H.A.C., 2016b. Scaling-up energy conservation initiatives: barriers and local strategies. Sustain. Cities Soc. 26, 227-239.

Veen, E., 2015. Community Gardens in Urban Areas: A Critical Reflection on the Extent to Which They Strengthen Social Cohesion and Provide Alternative Food. Wageningen University, Wageningen.

Wagenaar, H., Healey, P., Laino, G., Healey, P., Vigar, G., Riutort Isern, S., Honeck, T., Beunderman, J., van der Heijden, J., 2015. The transformative potential of civic enterprise. Plan. Theory Practice 16, 557-585.

Westerink, J., Kempenaar, A., van Lierop, M., Groot, S., van der Valk, A., van den Brink, A., 2017. The participating government: shifting boundaries in collaborative spatial planning of urban regions. Environ. Plan. C: Gov. Policy 35, 147-168.

Wiering, M., Immink, I., 2006. When water management meets spatial planning: a policyarrangements perspective. Environ. Plan. C: Gov. Policy 24, 423-438.

Yin, R.K., 2003. Case Study Research : Design and Methods, 3 ed. Sage, Thousand Oaks, CA [etc.]. 